\title{
Interstitial deletion of chromosome 10q23: a new case and review
}

\author{
S A Farrell, W Szymonowicz, G Chow, A M Summers
}

\begin{abstract}
A new case of a deletion of $10 \mathrm{q} 23$ is described. Only two other deletions involving this region have been previously noted. A review of clinical features of these three children did not show a distinct pattern of dysmorphic features. Other interstitial deletions of 10q are listed.
\end{abstract}

( $\mathcal{F}$ Med Genet 1993;30:248-50)

Few interstitial deletions of the long arm of chromosome 10 have been noted. We describe a new case presenting with microcephaly and developmental delay. The deletion of 10q23 of our patient is smaller than any reported previously. The features of others are reviewed but there does not appear to be a specific pattern of dysmorphic features associated with a deletion of this chromosomal region.

\section{Case report}

Developmental delay was observed in the proband, a white male, at 8 months. Chromosome analysis was normal initially but with high resolution banding an interstitial deletion of

The Credit Valley

Hospital, 2200

Eglinton Avenue

West, Mississauga,

Ontario, Canada L5M

2 N1.

S A Farrell

W Szymonowicz

G Chow

A M Summers

Correspondence to Dr Farrell.

Received 10 April 1992. Revised version accepted 30 July 1992.
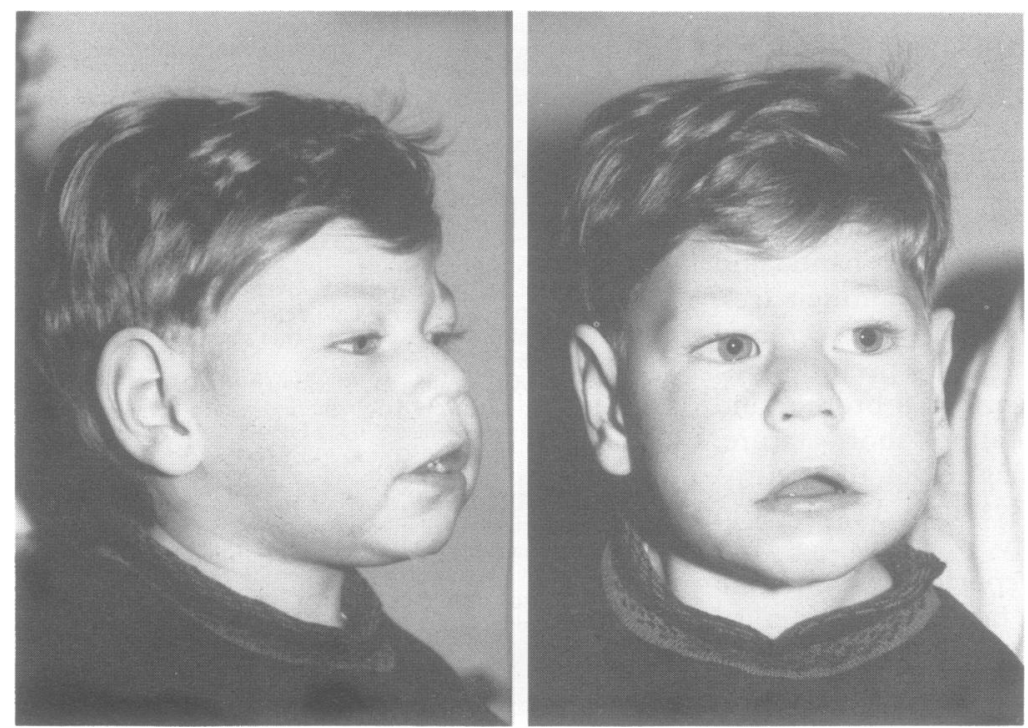

Figure 2 Facial appearance at 28 months.
$10 \mathrm{q}$ was detected. His karyotype is $46, \mathrm{XY}$, $\operatorname{del}(10)(\mathrm{q} 22.3 \mathrm{q} 23.2)$ or (q23.2q24.1) (fig 1). The banding pattern in this region does not allow discrimination between these two bands. Both parents had normal chromosomes. A permanent cell line has not been established.

His mother consumed a maximum of two drinks of alcohol per week throughout pregnancy. At term, birth weight was $3650 \mathrm{~g}$ (75th centile) and OFC was $<3$ rd centile. The neonatal course was complicated by hypoglycaemia treated briefly by intravenous glucose. A cardiac murmur was audible although an echocardiogram was normal. Early feeding was difficult with frequent gagging and vomiting. By 9 months he was rolling but not sitting. He could reach for toys but was not transferring objects from hand to hand. The OFC was $38 \mathrm{~cm}$ ( $<<3$ rd centile), height was on the $3 \mathrm{rd}$ centile, and weight was $>3$ rd centile. Head shape was dolichocephalic, with a posteriorly sloping forehead and hypoplastic midface, prominent maxilla, long philtrum, and small chin (fig 2). Palpebral fissures were upward slanting while the inner canthal distance was broad (40th centile). The nares were anteverted. He had a wide mouth with downturned corners, thickened alveolar ridges, and a short tongue frenulum. Peg shaped teeth were seen. The nipples were hypoplastic and there was a small umbilical hernia. Penile length was short $(<<3$ rd centile) and both testes were palpable. All toe nails were small. Although distally tone was significantly increased, proximally he was hypotonic. No other dysmorphic features were seen.

Normal investigations included a skull radiograph, head ultrasound, bone age, audiological and ophthalmological assessments, mucopolysaccharide and oligosaccharide screens, and urinary amino acid and organic acid screens. $\mathrm{He}$ is one of four sibs born to non-consanguineous parents. His sister and two brothers are well.

\section{Discussion}

Reports of $10 \mathrm{q}$ interstitial deletions are summarised in tables 1 and 2 . Three, including this case, involve $10 \mathrm{q} 23.12$ The de novo deletion of our patient is the smallest, involving $10 \mathrm{q} 23.1$ or 10q23.3. As these two bands are very similar in appearance, it is not possible to determine which is deleted. Non-specific features in common in these three children include postnatal onset of short stature, relative hypertelorism, and developmental delay. Some similarities of the facial area in two of three cases are anteverted nares, long philtrum, wide mouth with downturned corners, ocular anomalies, posi- 
Table 1 Interstitial deletions of 10q23.

\begin{tabular}{|c|c|c|c|}
\hline Characteristic & Mori et al ${ }^{1}$ & Shapiro et al & This report \\
\hline Karyotype & $\begin{array}{l}\text { 46,XY,del(10)(q23) } \\
\text { (de novo) }\end{array}$ & $\begin{array}{l}\text { 46,XX,del(10)(q23) } \\
\text { (de novo) }\end{array}$ & $\begin{array}{l}46, \mathrm{XX}, \operatorname{del}(10)(\mathrm{q} 23) \\
\text { (de novo) }\end{array}$ \\
\hline $\begin{array}{l}\text { Height (centile) } \\
\text { Head circumference (centile) }\end{array}$ & $\begin{array}{l}<3 \text { rd } \\
98 \text { th }\end{array}$ & $\begin{array}{c}\text { 3rd } \\
<3 \text { rd }(>90 \text { th at birth })\end{array}$ & $<<3$ rd \\
\hline $\begin{array}{l}\text { Head } \\
\text { Prominent occiput }\end{array}$ & & & \\
\hline $\begin{array}{l}\text { Prominent occiput } \\
\text { Broad forehead }\end{array}$ & + & $\begin{array}{l}+ \\
+\end{array}$ & $\overline{-}$ \\
\hline Shallow supraorbital ridges & & + & Prominent \\
\hline Low set ears & + & + & - \\
\hline \multicolumn{4}{|l|}{ Ocular region } \\
\hline Epicanthic folds & & + & + \\
\hline Relative hypertelorism & + & + & + \\
\hline Other & Glaucoma & Iris coloboma & \\
\hline Mouth wide, downturned & + & & + \\
\hline Nose small, anteverted & & + & + \\
\hline \multicolumn{4}{|l|}{ Palate } \\
\hline High arch & + & & + \\
\hline Bifid uvula & + & & - \\
\hline Scoliosis or kyphosis & + & + & - \\
\hline Extremities & Equinovarus $1-2$ toe gap & $\begin{array}{l}\text { Tapered fingers, proximally } \\
\text { placed thumbs, overlapping } \\
\text { toes, clinodactyly }\end{array}$ & - \\
\hline \multicolumn{4}{|l|}{ Nervous system } \\
\hline Hypotonia & + & & Abnormal \\
\hline Developmental delay & + & & + \\
\hline \multicolumn{4}{|l|}{ Abdomen } \\
\hline Umbilical hernia & & + & + \\
\hline Other & Urinary reflux & $\begin{array}{l}\text { Rectal prolapse, sensorineural } \\
\text { hearing loss, ptosis, frontal } \\
\text { hairline upswept }\end{array}$ & $\begin{array}{l}\text { Peg shaped teeth, small chin, } \\
\text { dolichocephaly, small penis }\end{array}$ \\
\hline
\end{tabular}

$+=$ present, $-=$ absent

Table 2 Other $10 q$ deletions.

\begin{tabular}{|c|c|c|c|c|c|c|c|}
\hline Author & Deletion & $\begin{array}{l}\text { Height } \\
\text { (centile) }\end{array}$ & $\begin{array}{l}\text { Head } \\
\text { circumference } \\
\text { (centile) }\end{array}$ & Ocular region & Extremities & $\begin{array}{c}\text { Developmental } \\
\text { delay }\end{array}$ & Other \\
\hline Ray $e t a l^{3}$ & $\mathrm{q} 21$ & 45 th & 50th & $\begin{array}{l}\text { Epicanthic folds, } \\
\text { hypertelorism }\end{array}$ & $\begin{array}{l}\text { Abnormal palmar } \\
\text { creases }\end{array}$ & + & $\begin{array}{l}\text { Short sternum, } \\
\text { ichthyosis, small penis }\end{array}$ \\
\hline Davis $e t a l^{4}$ & $\begin{array}{l}\text { q21q22 } \\
\text { de novo }\end{array}$ & $\mathbf{N}$ & $\mathbf{N}$ & $\begin{array}{l}\text { Telecanthus, } \\
\text { strabismus }\end{array}$ & & + & Hypotonia \\
\hline $\begin{array}{l}\text { Van de Vooren } \\
\text { et } a l^{5}\end{array}$ & $\mathrm{q} 24.2 \mathrm{q} 25.3$ (mat) & 50 th & $<10$ th & $\begin{array}{l}\text { Hypertelorism, } \\
\text { stabismus }\end{array}$ & $\begin{array}{l}\text { Pes planovalgus, } \\
\text { clinodactyly }\end{array}$ & + & $\begin{array}{l}\text { Sparse eyebrows, } \\
\text { cryptorchidism }\end{array}$ \\
\hline Holden and Macdonald ${ }^{6}$ & $\begin{array}{l}\text { q11.2q21 } \\
\text { de novo }\end{array}$ & 10th & 75th & Ptosis & $\mathbf{N}$ & + & $\begin{array}{l}\text { Hypotonia, } \\
\text { seizures }\end{array}$ \\
\hline Glover et $a l^{7}$ & $\begin{array}{l}\mathrm{q} 21.2 \mathrm{q} 22.1 \\
\text { de novo }\end{array}$ & $<3$ rd & $<3$ rd & Telecanthus & & + & $\begin{array}{l}\text { Plagiocephaly, } \\
\text { cutis laxa, hypotonia }\end{array}$ \\
\hline Rooney et $a l^{8}$ & $\begin{array}{l}\mathrm{q} 25.2 \mathrm{q} 26.1 \\
\text { de novo }\end{array}$ & & & Hypertelorism & & + & $\begin{array}{l}\text { Microbrachycephaly, } \\
\text { hypotonia }\end{array}$ \\
\hline $\begin{array}{l}\text { Durum and Lawce9 } \\
\text { Fryns et al }\end{array}$ & $\begin{array}{l}\mathrm{q} 11.2 \mathrm{q} 21.2 \\
\mathrm{q} 11.23 \mathrm{q} 21.2 \\
\text { de novo }\end{array}$ & $<3$ rd & $<3$ rd & Cataract & & & $\begin{array}{l}\text { Cockayne syndrome } \\
\text { diagnosed as young adult }\end{array}$ \\
\hline Curry and Zorn ${ }^{11}$ & $\begin{array}{l}\text { q21.2q } 22.1 \\
\text { de novo }\end{array}$ & & & & & + & \\
\hline Derksen et al ${ }^{12}$ & $\mathrm{q} 11.2 \mathrm{q} 21.1$ (mat) & & & & & & $\begin{array}{l}\text { Normal mother and } \\
\text { grandmother with same } \\
\text { deletion }\end{array}$ \\
\hline Lobo et $a l^{13}$ & $\begin{array}{l}\mathrm{q} 11.2 \mathrm{q} 22.1 \\
\text { de novo }\end{array}$ & $\mathrm{N}$ & $\mathrm{N}$ & $\begin{array}{l}\text { Strabismus, } \\
\text { hypertelorism }\end{array}$ & $\begin{array}{l}\text { Digitalised } \\
\text { thumbs }\end{array}$ & + & $\begin{array}{l}\text { Hypotonia, } \\
\text { prominent philtrum }\end{array}$ \\
\hline
\end{tabular}

$+=$ present, $\mathrm{N}=$ normal .

tional ear anomalies, epicanthic folds, broad forehead, and microcephaly. In particular the shape of the mouth of the case of Mori et al ${ }^{1}$ resembled our patient. An umbilical hernia, sacral dimple, and scoliosis or kyphosis were noted in two of three reports. ${ }^{12}$ There are no strikingly unusual features present in all three. Phenotypic variability could result from different breakpoints, causing loss or disruption of diverse genes, alternate alleles, position effect, and perhaps imprinting. However, this region has not been noted to have a mouse homologue where imprinting has been suspected. ${ }^{14}$ As there are so few cases of deletions of this region, it is difficult to say whether there is a recognisable pattern of features.

Relatively few other deletions of the long arm of chromosome 10 have been reported. These are listed in table 2. These deletions have variable breakpoints, spanning much of the long arm of chromosome 10. Given the differing breakpoints, variable clinical features are expected. These are reviewed further by Lobo et al. ${ }^{13}$ Shapiro et $a l^{2}$ detected a deletion of $10 \mathrm{q} 21$ compounded by a deletion of $10 \mathrm{q} 26.3$ and of the terminal portion of $13 \mathrm{p}$. In view of the other chromosomal anomalies, this case is not listed. Terminal deletions with more distal breakpoints have been reviewed by Wulfsberg et al. ${ }^{15}$ Chieri and Iolster ${ }^{16}$ described a large terminal deletion overlapping 10q23. This case was not reported in detail and separation of features found in 10q23 deletions from those associated with more distal deletions is not possible.

Clearly further reports of 10q23 deletions are needed to determine if a recognisable pattern of features is observable. This case reiterates the need to repeat testing when a chromosome anomaly remains a serious clinical consideration, despite an initially normal karyotype. 
1 Mori MS, Gomez-Sabrido F, de Bustamante AD, Pinel I, Martinez-Frias ML. De novo 10q23 interstitial deletion. f Med Genet 1988;25:209-12.

2 Shapiro SD, Hansen KL, Pasztor LM, et al. Deletions of the long arm of chromosome 10. Am f Med Genet 1985;20:181-96.

3 Ray M, Hunter AGW, Josifek K. Interstitial deletion of the long arm of chromosome 10. Ann Genet (Paris) long arm of chromosome 10. Ann Genet (Paris) 1980,23:103-4.

deletion. Am F Hum Genet 1982;34:122A.

5 Van de Vooren MJ, Planteydt HT, Hagemeijer A, PetersSlough MF, Timmerman MJ. Familial balanced insertion $(5 ; 10)$ and monosomy and trisomy $(10)(\mathrm{q} 24.2-\mathrm{q} 25.3)$. Clin Genet 1984;24:52-8.

6 Holden JA, MacDonald EA. Brief clinical report. Interstitial deletion of the long arm of chromosome 10: $\operatorname{del}(10)(\mathrm{q} 11.2 \mathrm{q} 21)$. Am $\mathcal{f}$ Med Genet 1985;20:245-9.

7 Glover G, Gabarrón J, Ballester LJA. De novo $10 \mathrm{q}(\mathrm{q} 21 \mathrm{q} 22)$

8 Rooney DE, Williams K, Coleman DV, Habel A. A case of interstitial deletion of 10q25.2-q26.1. F Med Genet 1989;26:58-60.
9 Durum C, Lawce H. Brain tickler. Appl Cytogenet $1991 ; 17: 35-6$

10 Fryns JP, Bulcke J, Verdu P, Carton H, Kleczkowska A Van den Berghe $H$. Apparent late-onset Cockayne syndrome and interstitial deletion of the long arm of chromosome 10 (del (10)(q11.23q21.2). Am 7 Med Genet $1991 ; 40: 343-4$

11 Curry $\mathrm{C}$, Zorn E. Cytogenetic findings at variance with referring diagnosis. Appl Cytogenet 1991;17:62.

12 Derksen C, Ramdhanie R, Wood M, Winsor E. Interstitial deletion in 10q with no apparent abnormalities. Appl

13 Lytogenet 1991;17:69. tial deletion of 10q: clinical features and literature review. tial deletion of 10q: clinical features

14 Hall JG. Genomic imprinting: review and relevance to Hall JG. Genomic imprinting: review and relevan
human diseases. Am $f$ Hum Genet 1990;46:857-73.

15 Wulfsberg EA, Weaver RP, Cunniff CM, Jones MC, Jones KL. Chromosome 10qter deletion syndrome: a review and report of three new cases. Am $\mathcal{F}$ Med Genet 1989; 32:364-7.

16 Chieri P, Iolster N. Monosomy 10qter due to a balanced maternal translocation: $t(10 ; 18)(\mathrm{q} 23 ; \mathrm{p} 23)$. Clin Genet 1983;24:147-50. 